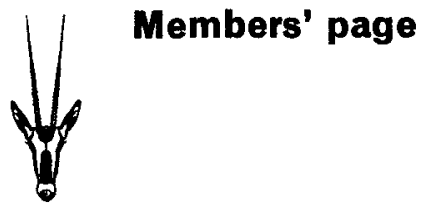

\title{
ANNUAL GENERAL MEETING
}

The agenda for the annual general meeting of the Society, to be held in the Zoo meeting rooms, Regent's Park, on Wednesday, June Ioth, at 6.0 p.m., will be found on page 267. The President, the Marquess of Willingdon, will take the chair. Following the business meeting Lady Lathbury will show films of East African wildlife, and Mr Nigel Sitwell, editor of Animals, will speak on his recent visit to South-east Asia. A wine and cheese supper will be served at 7.30 p.m.-please fill in the pink form enclosed with this issue of ORYX if you would like this. By kind invitation of the Zoological Society all those attending the meeting are welcome to walk round the Zoo, which is having an open evening for Fellows, until I I.o p.m.

\section{'THE LAST OF THE WILD'}

There were good and enthusiastic audiences for the four London performances, at the New Gallery Cinema in March, of the Society's splendid new two-hour colour film. 'The Last of the Wild', by Eugen Schuhmacher. The first performance was attended by TRH the Duchess of Gloucester and Prince Richard. The second performance for schools, organised by the World Wildlife Youth Service, was completely sold out, as was the last performance on Sunday, March 22nd. The film is now being shown in different parts of the country as the FPS's contribution to European Conservation Year; details are on the yellow leaflet enclosed with this ORYX.

\section{MADAGASCAR CONFERENCE}

Members of the Society who would be interested in attending a conference in Madagascar in early October, under the auspices of IUCN to discuss wildlife conservation in the island, and especially the endemic lemurs, are asked to write to Miss Giles for details. The four-day conference will be followed by field excursions to see the island's remarkable wildlife (comfortable but not luxury standards), the whole stay being for about two weeks. The basic cost (excluding field trips but including hotel charges in Tananarive) will be about $£ 250$.

\section{ORYX BY AIR}

ORYX can be sent airmail to overseas members at the following extra charges:- Ethiopia, Sudan, Middle East; I4s; Africa (the rest), Asia, Antarctica, Canada, USA, South America, West Indies: I6s 8d (\$2.00); Australia, Japan, Pacific: $19 s$ d (\$2.50). 